\title{
A scientific note on a new pest for European honeybees: first report of small hive beetle Aethina tumida, (Coleoptera: Nitidulidae) in Italy
}

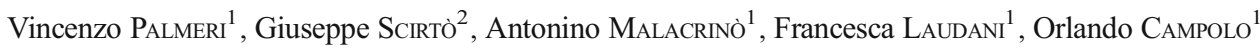 \\ ${ }^{1}$ Dipartimento di AGRARIA, Università "Mediterranea" of Reggio Calabria, Reggio loc Feo di Vito, 89122, Reggio Calabria, Italy \\ ${ }^{2}$ Associazione Regionale Allevatori Calabria, Lamezia Terme, CZ, Italy
}

Received 8 September 2014 - Revised 13 November 2014 - Accepted 9 December 2014

small hive beetle / symbiont / biological / invasion / honeybee

The small hive beetle (SHB), Aethina tumida Murray (Coleoptera Nitidulidae), is an important pest of honeybees in many parts of the world. The beetle is native to sub-Saharan Africa and was unintentionally introduced into USA (1996), Australia (2001) and in Canada (2002) (Ellis and Munn, 2005; Neumann and Ellis 2008). In Europe the SHB was discovered in 2005 in a consignment of queens imported from Texas (USA) into Portugal and destroyed by the Portuguese National Veterinarian Services (Murilhas, 2005). Since then, Europe remained free from this pest.

A. tumida (Figure 1) lays eggs in cracks and crevices inside hives. Eggs are pearly white, 1.4-mm long by $0.26-\mathrm{mm}$ wide. They are normally incubated from 1 to 6 days, but the majority hatch in 2 to 4 days. The larvae, which are the damaging stage of SHB, have relatively large heads and a series of protuberances all over their bodies (Figure 2); The SHB develops until wandering stage and then leaves the hive for pupation in the soil (Lundie, 1940; Neumann et al. 2013; OIE, 2013). Newly emerged adults invade host colonies detecting stressed colonies form a distance of about $13-16 \mathrm{~km}$. However, SHB can also intrude strong honeybee colonies bypassing

Electronic supplementary material The online version of this article (doi:10.1007/s13592-014-0343-9) contains supplementary material, which is available to authorized users.

Corresponding author: O. Campolo, orlando.campolo@unirc.it

Manuscript editor: Yves Le Conte the guard bees (Ellis 2005; Neumann and Elzen, 2004). Small hive beetles may develop also in fruits (avocado, cantaloupe, grapefruit and others), but fewer offspring are produced on these foodstuffs than on bee products such as pollen (Arbogast et al., 2010; Ellis et al., 2002). African honeybee subspecies are considered more resistant to the SHB than European honeybee subspecies (Neumann and Elzen, 2004).

During a survey carried out in Calabria (southern Italy), in September 2014, several specimens (both adults and larvae) of $A$. tumida were unexpectedly found inside three Apis mellifera ligustica Spinola colonies, maintained in wood nuclei with five frames. The original research aimed to evaluate the side effects of selected insecticides to honeybees, applied against the arrowhead scale Unaspis yanonensis (Kuwana), recently introduced in Calabria (Campolo et al., 2013).

The bee colonies were placed in the spring of 2014 in a citrus orchard located in Sovereto (Gioa Tauro, Reggio Calabria, Italy) near the harbour of Gioia Tauro (RC); the colony strength was checked monthly by estimation of the frames' area occupied by bees. Until the first week of July, all the bee colonies were healthy, queenright and, except from Varroa mites, no other parasite was observed. On September 5th, several adult beetles (online resource Figs. S1, S2 and S3) were manually collected on the bottom board, and hypothesizing that these were specimens of SHB, the hives were immediately isolated by placing them individually inside plastic bags. The colonies were killed by adding ethyl acetate and transported to the laboratory of Entomology of the 


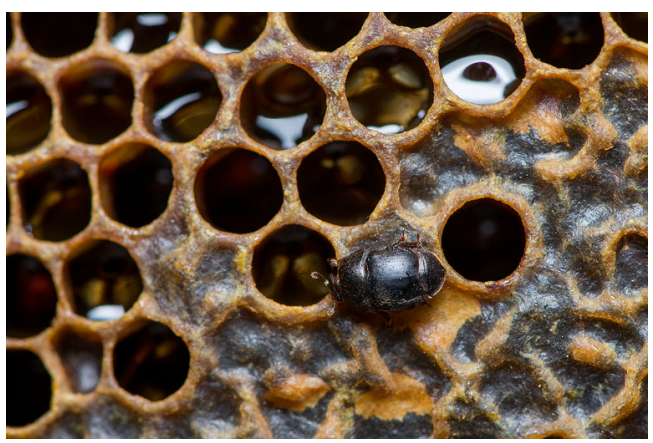

Figure 1. Aethina tumida adult found in the infested hives walking on a honeycomb.

AGRARIA Department, University Mediterranea of Reggio Calabria (Italy). After the definitive confirmation of SHB according to Larson (2013), OIE (2013), Habeck (2002) and Lundie (1940), the day after the sampling, a soil treatment employing chlorpyrifosmethyl (Reldan 22, Bayer, Italy) was carried out in order to kill buried larvae. Since the SHB is in Europe a compulsorily notifiable pest, a detailed official communication was notified to the local veterinary authorities the same day of the discovery. During an inspection carried out during the following days, other two treatments to soil were carried out in the presence of the public veterinary services. No pupae were found in the soil during inspection.

All the three bee colonies were infested by SHB, but only adult specimens and larvae collected in the bottom boards and in one lateral comb were counted (20 adults and 192 larvae), because the other samples (stored at $-80{ }^{\circ} \mathrm{C}$ ) were requested and subsequently delivered to the National Reference Centre for apiculture (IZSVe Istituto Zooprofilattico Sperimentale delle Venezie). The larvae were found mainly crowded inside the cells in the lowest part of the comb; no wandering larvae

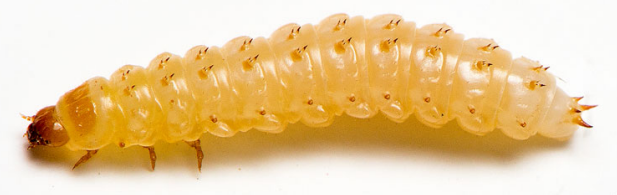

Figure 2. Lateral view of Aethina tumida larva found in the infested hives. were observed outside the nuclei. Voucher specimens (both larvae and adults) were deposited at the AGRA RIA Dept., University Mediterranea of Reggio Calabria (Italy).

During the following weeks, the monitoring was conducted, as required by Italian law, by the local veterinary authorities coordinated by the Ministry of Health and the National Reference Centre (IZSVe). A $20-\mathrm{km}$ protection zone and $100-\mathrm{km}$ surveillance zone around the infested colonies were checked by the veterinary authorities and the epidemiological situation is constantly updated on the IZSVe website (www.izsvenezie.it).

The SHB source of the outbreak is unknown as well as the date of introduction. SHB may have arrived through the harbour of Gioia Tauro, where goods transit from all over the world, by bee commercial trades or by hive movement. In the area in which A. tumida was discovered, the presence of apiaries coming from other Italian regions is high (thousand of hives) from April (citrus blooming) until July (kiwi fruit pollination service). This aspect may have also facilitated the spread of the parasite.

Herein we provide the first report of $A$. tumida in Italy and Europe to alert beekeepers, researchers and regulators to be vigilant to prevent the diffusion of this invasive pest throughout Europe.

\section{ACKNOWLEDGMENTS}

Dr. Giacomo Falcone took all photographs included in this manuscript.

Note scientifique sur un nouvel ennemi des abeilles européennes: première observation du petit coléoptère des ruches Aethina tumida (Coleoptera: Nitidulidae) en Italie

Eine wissenschaftliche Notiz über einen neuen Schädling der Europäischen Honigbiene: der erste Bericht über das Auftreten von Aethina tumida (Coleoptera, Nitidulidae) in Italien

\section{REFERENCES}

Arbogast, R.T., Baldwyn, T., Teal, P.E.A. (2010) Potential for population growth of the small hive beetle Aethina tumida (Coleoptera: Nitidulidae) on diets of pollen dough and oranges. Fla. Entomol. 93 (2), 224-230

Campolo, O., Malacrinò, A., Maione, V., Laudani, F., Chiera, E., Palmeri, V. (2013) Population dynamics and spread of Unaspis yanonensis in Calabria, Italy. Phytoparasitica 41 (2), 151-157 
Ellis, J.D., Neumann, P., Hepburn, H.R., Elzen, P.J. (2002) Longevity and reproductive success of Aethina tumida (Coleoptera: Nitidulidae) fed different natural diets. J. Econ. Entomol. 95, 902-907

Ellis, J.D. (2005) Reviewing the confinement of small hive beetles (Aethina tumida) by western honey bees (Apis mellifera). Bee World 86(3), 56-62

Ellis, J.D., Munn, P.A. (2005) The worldwide health status of honey bees. Bee World 86(4), 88-101

Habeck D. H. (2002) Nitidulidae, in Arnett, R. H., Thomas, M. C., Skelley, P. E., Frank, J. H. (Eds.). American Beetles: Polyphaga: Scarabaeoidea through Curculionoidea (Vol. 2). CRC Press. pp 311-315

Larson, D. (2013) Key to Saskatchewan species of Nitidulidae (sap beetles) and Kateretidae (short-winged flower beetles). http://www.entsocsask.ca/insect lists.html (Accessed on 08 September 2014)

Lundie A.E. (1940) The small hive beetle Aethina tumida, Sci. Bull. 220, Dept. Agric. Forestry, Government Printer, Pretoria, South Africa.
Murilhas, A. (2005) Aethina tumida arrives in Portugal. Will it be eradicated? EurBee Newsletter 2, 7-9

Neumann, P., Ellis, J.D. (2008) The small hive beetle (Aethina tumida Murray, Coleoptera: Nitidulidae): distribution, biology and control of an invasive species. J. Apic. Res. 47 (3), 181-183

Neumann, P., Elzen, P.J. (2004) The biology of the small hive beetle (Aethina tumida, Coleoptera: Nitidulidae): Gaps in our knowledge of an invasive species. Apidologie 35 (3), 229-248

Neumann, P., Evans, J. D., Pettis, J. S., Pirk, C. W. W., Schäfer, M. O., Tanner, G., Ellis, J. D. (2013) Standard methods for small hive beetle research, in $\mathrm{V}$. Dietemann, J.D. Ellis, P. Neumann (Eds) The COLOSS BEEBOOK, Volume II: standard methods for Apis mellifera pest and pathogen research. J. Apic. Res., 52 (4): 32 pp.

OIE, (2013) Small hive beetle infestation (Aethina tumida) http://www.oie.int/fileadmin/Home/eng/Health_standards/ tahm/2.02.05_SMALL_HIVE_BEETLE.pdf (Accessed on 12 November 2014) 